\title{
Ignorantia juris
}

Beware the long arm of the law.

\section{Gareth Owens}

There was always a remote possibility of a time traveller turning up from the moment the Large Hadron Collider went live, but judging by the looks on their faces, I got the feeling that they weren't really expecting one.

Scientists are like that. They'll tell you they think something is possible, like time travel or life on Mars, just to get you excited about funding them, but they don't really believe it themselves because they don't believe in magic. However, much as they'd have liked to, they were never able to find the bit in the details of the Universe that would render spooky old time travel impossible.

I arrived in a puff of something that looked like smoke and felt like semolina, standing with my briefcase held before me like a shield. For me, I neither need to believe nor disbelieve - I'm a lawyer - and on this trip I was a paying passenger of the Temporal Railroad Company of 2177.

If I'd landed on target I'd be standing on the minus side of the Compact Muon Solenoid, under the main shaft. I looked around, still feeling queasy. The green paint of the aluminium inspection platform seemed impossibly bright and the smell of concrete and ozone was exactly like the mock-up in the time station. I blinked a couple of times, and the relief forced the tension to let go of my shoulders. I had made it.

The LHC was the first machine to create subatomic temporal distortions, no good for time travel in themselves, but they formed the zero datum point from which a time machine existed, and so the later technologies based on low-dimensional temporal geometry were able theoretically to exploit this as the end of a railway line. I say 'theoretically' because in 2050, my year of travel, nobody had ever gone back that far. When I told the company my intended destination they flatly refused, at first.

The LHC, they explained, isn't so much the last station on the line, as the buffers at the end of it. It was all Geek to me, and they could throw as much of it at me as they liked. I had a place and a time and a very special client, and they were going to send

me there, and my company was not one to be denied lightly.

My watch had already been set to local time. I had a little bit of running to do, then three minutes of hiding, before I could walk out on the back of a tour group. My briefcase contained everything I needed to blend into the background. I was amazed at the calm faces of the staff I saw as I moved

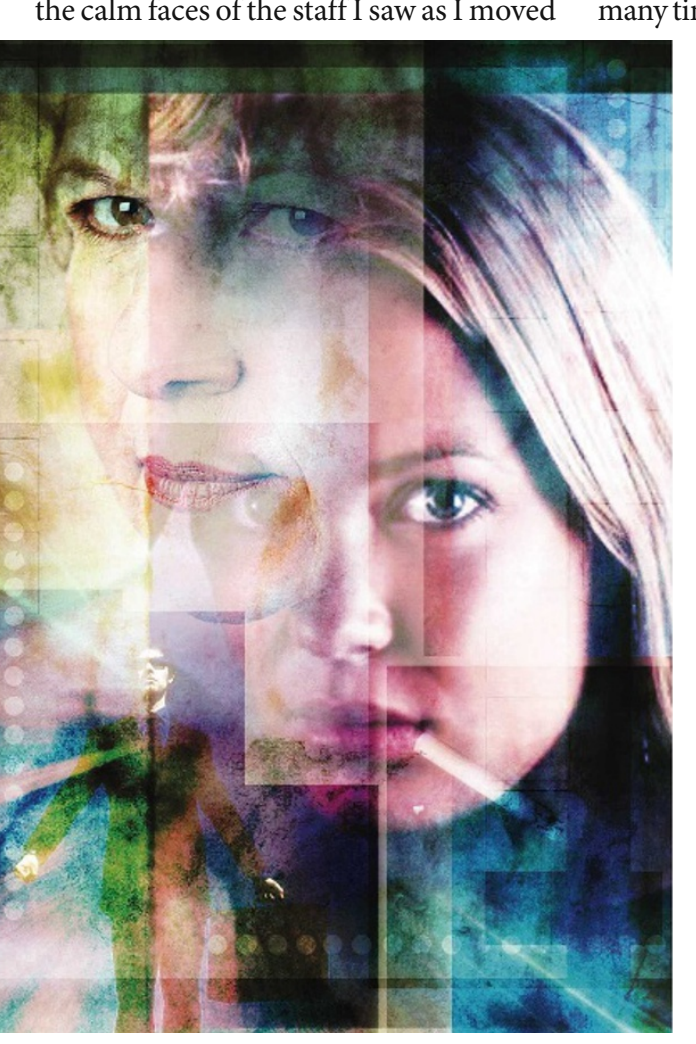

around the place. They had built this completely amazing machine, designed to throw energies around on a scale previously never envisaged, and they had no expectation of anything amazing happening, like a lawyer from the future falling out of a wormhole.

I had planned my exfiltration based on camera timings and security logs from the online archive. I was particularly keen not to get caught. I hadn't come back 40 years to spend the next 40 rendered to an existence-denied prison somewhere extraordinary.

Aside from a few technological items that were meant to ease my escape from Switzerland, my briefcase was also full of period traveller's cheques and temporally valid ID, so I left CERN behind relatively easily and made my way to Amsterdam.

I knew where to find her because of the arrest records. I got there about an hour before she was due to be raided for drugs.
Her name was Barbi Bodega, and she was worth all the risks. She was lead singer of Franken Ken. I leaned on the bell until she emerged into the pale summer sunlight. She stood in the doorway, a cigarette drooping from her famous pout and a child held to her hip. She was just the way she was in the photos: her hair bleached and dyed so many times that the texture was like carpet, her skin corpse white. She smelled of vomit and English gin.

"Consider yourself served," I said, giving her the papers. She squinted at the summons.

"I'm being sued?" her voice, contralto and wrecked by alcohol, broke with the surprise. "What for? Who by?"

I reached out and tickled the baby's chin.

“Barbi Bodega 2050," I said.

"What?" She really didn't have a clue. Nothing like the woman I remembered.

"Barbi Bodega in 2050 is 62 years of age," I said. "She is a radically different person from you, and she has inherited the body that you created for her, and all the medical problems that entails. To be honest I can't see her surviving another summer like the last one. And she wants what you owe her, another 20 years of life. So she's suing you for reckless endangerment and is applying for sequestration of all the profits from your last two albums."

"You're having a laugh ain'tcha? Lawyer from the future? No such thing."

"Oh I admit, this will be the first time your legal system has come across one, but I have been temporal specialist with Boylett, Wisty and Grole for the past 20 years, and most of the legislation I need is already in place. The Temporal Bar Association calls it accidental case-law. Trust me on this, I'm going to win, and my Barbi Bodega is going to get what the people who care about her really want for her ... more life."

"But you can't take all of my money. How am I going to live? I've got a kid now, how am I supposed to look after him?"

I turned and walked away.

"Don't worry about him," I said. "He grows up to be a lawyer."

Gareth Owens, trained in Babylonian wizardry, lives under a huge yew tree with a one-eyed cat called Freddy, where he drinks too much coffee and makes stuff up. 